\title{
SOME PHYSICAL AND MECHANICAL CHARACTERISTICS OF PALM DATE FRUITS
}

\author{
El-Bessoumy, R. R.*
}

\begin{abstract}
\end{abstract}
The present study aimed to determine and recognize some physical and mechanical properties as an important role in designing and developing of specific machines and their operations. Some physical and mechanical characteristics of date fruits (Phoenix dactylifera L), Joezee variety, were determined. These characteristics included the date dimensions, surface area, mass, bulk density, real density, void ratio, moisture content, repose angle, static friction coefficient and rigidity force. For each dimension, the date fruits gave the highest value in width of $42.9 \mathrm{~mm}$, the lowest value in length of $25.9 \mathrm{~mm}$. the highest value of repose angle was $26.1^{\circ}$ for galvanized sheet while the lowest value was $16.4^{\circ}$ for glass. The date fruits gave the lowest value of static coefficient of friction of 0.12 for ply wood while the highest value was 0.17 for galvanized sheet.

\section{INTRODUCTION}

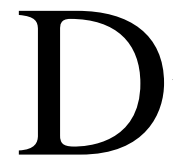
ate palm is one of the most important horticulture crops rich in vitamins. Date production in the world is only confined to a small number of countries, most of them being the Arab countries. Date palm is the economic crop in Egypt, where production was approximately 1470 thousand tons of dates, FAO (2012). However, the date industry in the Arab world is not yet fully developed. Great efforts were carried out to evaluate the basic physical and mechanical properties of some agricultural materials to point out their practical utility in machine structural design and food processes, Waziri and Mittal (1993). Dates provide a wide range of essential nutrients, and are a very good source of dietary potassium. The sugar content of ripe dates is about 80\%; the remainder consists of protein, fiber, and trace elements including boron, cobalt, copper, fluorine, magnesium, manganese, selenium, and zinc, Al-Shahib and Marshall (2003).

*Lecturer of Ag. Constructions and Environmental Control Eng. Dept., Fac. of Ag. Eng., Al-azhar Univ., Cairo, Egypt. 
Knowledge of the physical properties of date fruit is necessary for the design of post harvesting equipment such as cleaning, sorting, grading, kernel removing, and packing. The importance of dimensions is in determining the aperture size of machines, particularly in separation of materials as discussed by Mohsenin (1986).

Nesvadba, et. al. (2004) mentioned that the physical characteristics of the material such as shape, size, volume, density, surface area and coefficient of friction are important and essential engineering data in design of machine structures, and controls, in analyzing and determining the efficiency of a machine or an operation. Many authors: \{Akubuo and Odigboh (1999), Abou-Elmagd, et al. (2002), Awady et al. (2004), El Sayed et al. (2009) and Yehia et al. (2009)\} mentioned that the knowledge of the physical and mechanical characteristics of agricultural products is important in the design, of agricultural machines and equipment. They studied the physical properties and characteristics of some agricultural crops and fruits, which can be used in the design and development of equipment.

Several investigations have shown some of the chemical compositional changes that take place during maturation, including free sugars and tannins Myhara et al., (1999); Sawaya et al., (1983); Sawaya et al., (1982). Green dates stage (kimri) are firm in texture with highest moisture and tannin contents. At the Khalaal stage, dates begin to lose moisture and form considerable quantities of sucrose. In the Rutab stage, the loss of moisture is accelerated, and the fruits become softer in texture, and sucrose is converted into sugars. Dates at Rutab stage are the most desirable since they are at their softest and sweetest states. In the final maturity stage the fruits contain the least amount of moisture and maintain a soft texture with a sweet taste. Ismail et al., (2001) studied the consumer preference for quality attributes of date (maturity of Tamr stage). Consumer gave weight on the acceptance as: high (color, appearance, and sweetness), medium (fruit size, flesh thickness, chewiness, and solubility).

The objective of the present research is to study some physical and mechanical properties of date fruits that can be used in fruits handling and classifications. 


\section{MATERIAL AND METHODS}

\section{Raw Material:}

Dates fruits, variety of Joezee, Fig. (1) used in this investigation were obtained from the local small market, Mansoura, Daqahlia Governorate.
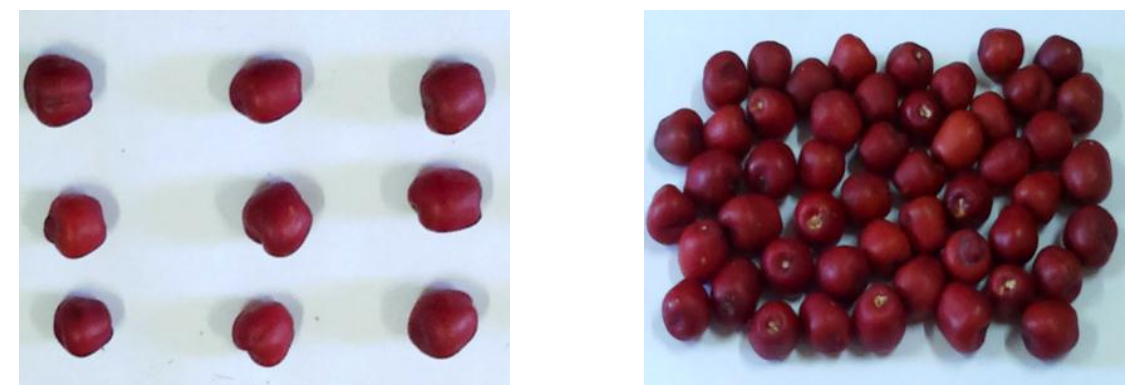

Fig. (1): Palm dates fruits.

This study was carried out at the Faculty of Agricultural Engineering, AlAzhar University, and Cairo, Egypt during season 2014. Physical and some mechanical characteristics of date fruits, Joezee variety which planted in Kuwait, were determined at maturity stage (Khaleal stage). Tests procedures:

Date fruits dimensions:

Physical characteristics can be utilized effectively in machines design, one of those physical characteristics is dimension characteristic as length, width, and thickness $(\mathrm{mm})$. Length and diameter $(\mathrm{mm})$ were measured by using digital dial caliber (accuracy of 0.01). One hundred and fifty 150 date fruits were randomly selected from the variety of Joezee. The two major dimensions, length (parallel with the longitudinal axle "a"), Diameter (perpendicular on the longitudinal axle "b") Fig. (2), of each fruit were recorded.

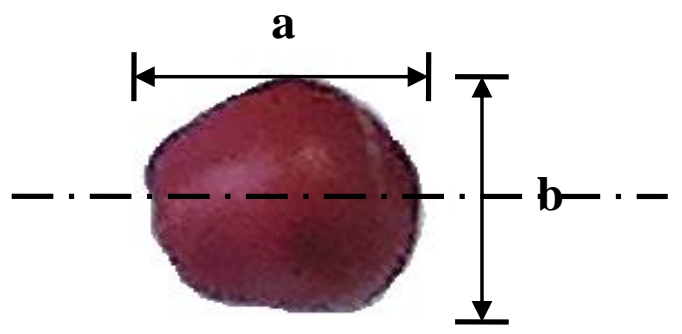

Fig (2): Length "a" and diameter "b" positions of individual date fruit. 


\section{Date fruits surface area:}

The surface area of date fruits is very important characteristic in determining both volumetric and gravimetric heat transfer coefficients and in analyzing heat and moisture transfer during drying processes, and it is also useful for describing the re-hydration process. The following relation was used for calculating the flat surface area $\left(\mathrm{A}_{\mathrm{f}}\right)$ in $\left(\mathrm{mm}^{2}\right)$, according to Matthews (1991) as:

$$
A_{f}=\frac{\pi}{4}(a \cdot b) \mathrm{mm}^{2}
$$

\section{Date fruits mass:}

A random sample of two hundred date fruits were taken manually and weighed by an electric digital balance, Sartorius: 1413-MP8-1, manufactured in Germany with capacities 500g and 5000g at accuracies $0.01 \mathrm{~g}$ and $0.1 \mathrm{~g}$ respectively. The mass of each treatment was replicated three times.

\section{Bulk density, real density and void ratio:}

\section{Bulk density:}

The bulk density was determined by using a graduated cylinder of 1000 $\mathrm{ml}$, the volume was determined by pouring ten date fruits in the pervious graduated cylinder Boumans, (1985) Kaleemullah (1992), each test was done in three replicates. The bulk density was calculated for the palm date fruits by dividing the mass of quantity of Palm date fruits on its volume, which was measured by using a graduated cylinder Matthews (1991) as:

$$
\rho_{b}=\frac{M_{b}}{V_{b}}
$$

Where:

$\rho_{b}:$ Bulk density of palm date fruits, $\left(\mathrm{kg} / \mathrm{m}^{3}\right) ;$

$M_{b}$ : Mass of the quantity of palm date fruits, $(\mathrm{kg})$; and

$V_{b}$ : Volume of the quantity of palm date fruits, $\left(\mathrm{m}^{3}\right)$. 
PROCESS ENGINEERING

\section{Real density:}

The real density was determined by measuring the actual volume (by using a graduated cylinder of $1000 \mathrm{ml}$ ) of a known mass of a random date fruits sample. The actual volume of the palm date fruits was determined by water displacement method, in a graduated measuring cylinder, the immersion time was about 10 second which was too small to absorb water. The density is calculated by finding the ratio of mass to volume of displaced water $\left(\mathrm{g} / \mathrm{mm}^{3}\right)$. The real density for each variety was replicated three times.

$$
\rho_{r}=\frac{M_{r}}{V_{r}}
$$

\section{Where:}

$\rho_{r}:$ Real density of palm date fruits, $\left(\mathrm{kg} / \mathrm{m}^{3}\right) ;$

$M_{r}$ : Mass of the quantity of palm date fruits, $(\mathrm{kg})$; and

$V_{r}$ : Volume of displaced water, $\left(\mathrm{m}^{3}\right)$.

\section{Void ratio:}

The void ratio $(\varepsilon)$ was achieved by the following equation:

$$
\varepsilon=1-\frac{\rho_{b}}{\rho_{r}}
$$

$\rho_{b}$ : Bulk density of palm date fruits, $\left(\mathrm{kg} / \mathrm{m}^{3}\right)$;

$\rho_{r}$ : Real density of Palm date fruits, $\left(\mathrm{kg} / \mathrm{m}^{3}\right)$;

\section{Date fruits moisture content:}

The moisture content was determined for the flesh of dates using AOAC procedures AOAC (1995) where the samples of date fruits were dried at $70^{\circ} \mathrm{C}$ for 48 hours. The moisture content was calculated on wet and dry basis as follows:

Moisture content "M.C" wet basis, (\%): 


$$
M . C=\frac{W_{m}}{W_{m}+W_{d}} \times 100
$$

Moisture content " $M$ " dry basis, (\%):

$$
M=\frac{W_{m}}{W_{d}} \times 100
$$

Where:

$W_{m}$ : Mass of moisture in sample, $(\mathrm{g})$; and

$W_{d}$ : Mass of bone-dry material, $(\mathrm{g})$.

\section{Repose angle:}

The angle of repose of date fruits was measured. The dynamic angle of repose was measured between the horizontal and the natural slope of the fruits heap, the different material surfaces namely: plywood, glass and galvanized sheet were used for measuring. The height of the heap was measured and the dynamic angle of repose was calculated by the following equation Kaleemullah (1992) and Soliman (1994)

$$
\alpha=\tan ^{-1}\left(\frac{2 H}{D p}\right)
$$

Where: $\alpha=$ dynamic angle of repose, degree.

$$
\begin{aligned}
& H=\text { heap height, } \mathrm{mm} \text { and } \\
& D_{p}=\text { platform diameter, } \mathrm{mm} .
\end{aligned}
$$

The dynamic angle of repose for date fruits was including three replicates.

\section{Static friction coefficient:}

The test procedure started by leveling the apparatus that was fabricated in the workshop of Agricultural Engineering Faculty, Al-azhar University, Nasr city, Cairo, Egypt. The apparatus was used to measure the angle of static friction for the different material surfaces, namely: plywood, glass and galvanized sheet. The static coefficient of friction was determined using the following equation Mohsenin (1986).

$$
\text { Static coefficient of friction }=\tan \theta
$$


Where:

$\theta=$ the tilt angle between the surface and the horizontal.

The angle of friction $(\theta)$ was measured three times for each selected materials for Date fruits.

\section{Rigidity force:}

A digital force gauge (SHIMPO, DF-5.0 series) with accuracy of $\pm 0.2 \%$ was used for measuring the rigidity force with maximum capacity of $2200 \mathrm{~g}$. The rigidity force was recording of each date fruit in two surface positions (vertical and horizontal) after installing the Cone sensing head in the digital force gage. The rigidity force was recording three replicates for each date fruit.

\section{RESULTS AND DISCUSSIONS}

Some physical and mechanical characteristics of date fruits under study were conducted in the laboratory of Physical Properties at Faculty of Agricultural Engineering, Al-azhar University.

\section{The two- Major dimensions:}

Averages of three replicates for the two-major dimensions are shown in table (1). The measurements of length (a) and diameter (b) in ( $\mathrm{mm}$ ) of hundred and fifty date fruits, randomly selected, were conducted. The highest value of date fruit length and diameter was 36.8 and $42.9 \mathrm{~mm}$ respectively, while the lowest values of date fruit length and width were 25.9 and $28.1 \mathrm{~mm}$ respectively.

Table (1): The two - Major dimensions of date fruits.

\begin{tabular}{|c|c|c|c|c|c|}
\hline $\begin{array}{c}\text { Two-major } \\
\text { dimensions }\end{array}$ & Max. & Min. & Ave. & S.D & C.V \% \\
\hline Length (mm) & 36.8 & 25.9 & 32.8 & 2.23 & 0.06 \\
\hline Diameter (mm) & 42.9 & 28.1 & 33.8 & 2.44 & 0.07 \\
\hline
\end{tabular}

Fig. (3 and 4) indicated that the highest frequencies of date fruit length and diameter were 33.3 and $40 \%$ at $(33.5-35.3 \mathrm{~mm})$ and $(30.8-33.3$ $\mathrm{mm})$ respectively. Dimensions are important to design the cleaning, sizing and grading machines. 


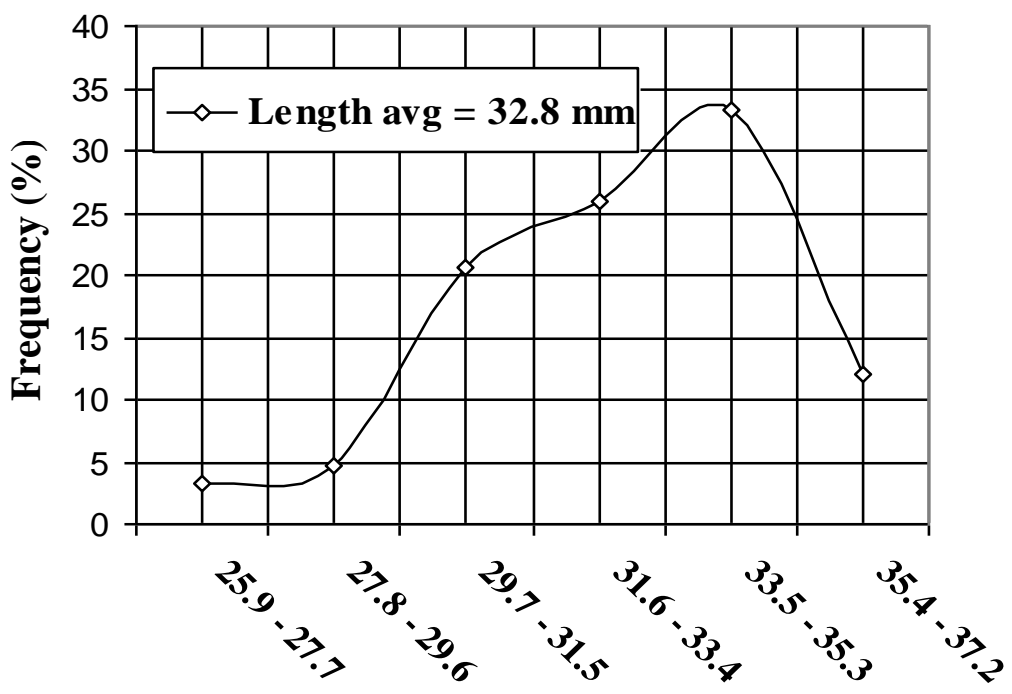

Dimensions cate gories in $(\mathrm{mm})$

Fig. (3): Length of date fruits.

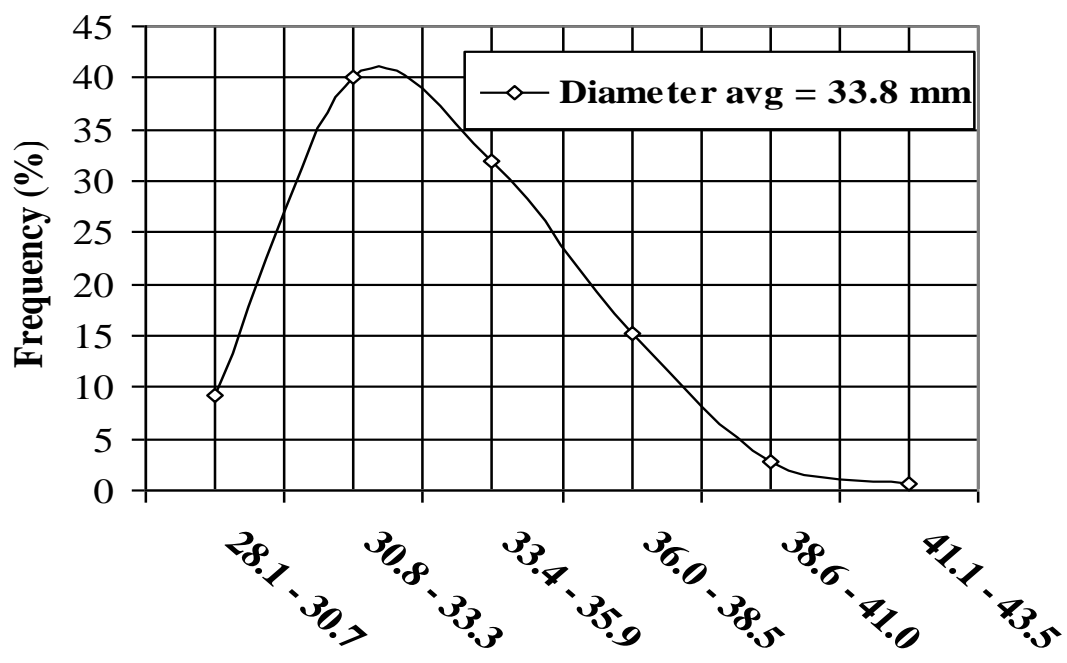

Dimensions categories in $(\mathbf{m m})$

Fig. (4): Diameter of Date fruits.

\section{Date fruits surface area:}

Table (2) shows the flat surface area of date fruits. The maximum value of flat surface area is $1239.9 \mathrm{~mm}^{2}$, while the minimum value is $571.6 \mathrm{~mm}^{2}$. 
Fig. (5) shows that the highest frequency of date fruit flat surface area was $32 \%$ at $\left(89.9-98.6 \mathrm{~mm}^{2}\right)$.

Table (2) Flat surface area of date fruits.

\begin{tabular}{|c|c|c|c|c|c|}
\hline $\begin{array}{c}\text { Date fruit } \\
\text { surface area }\end{array}$ & Max. & Min. & Ave. & S.D & $\begin{array}{c}\text { C.V } \\
\text { \% }\end{array}$ \\
\hline $\begin{array}{c}\text { Flat surface } \\
\text { area }\left(\mathbf{m m}^{2}\right)\end{array}$ & 1239.9 & 571.6 & 874.2 & 120.23 & 0.14 \\
\hline
\end{tabular}

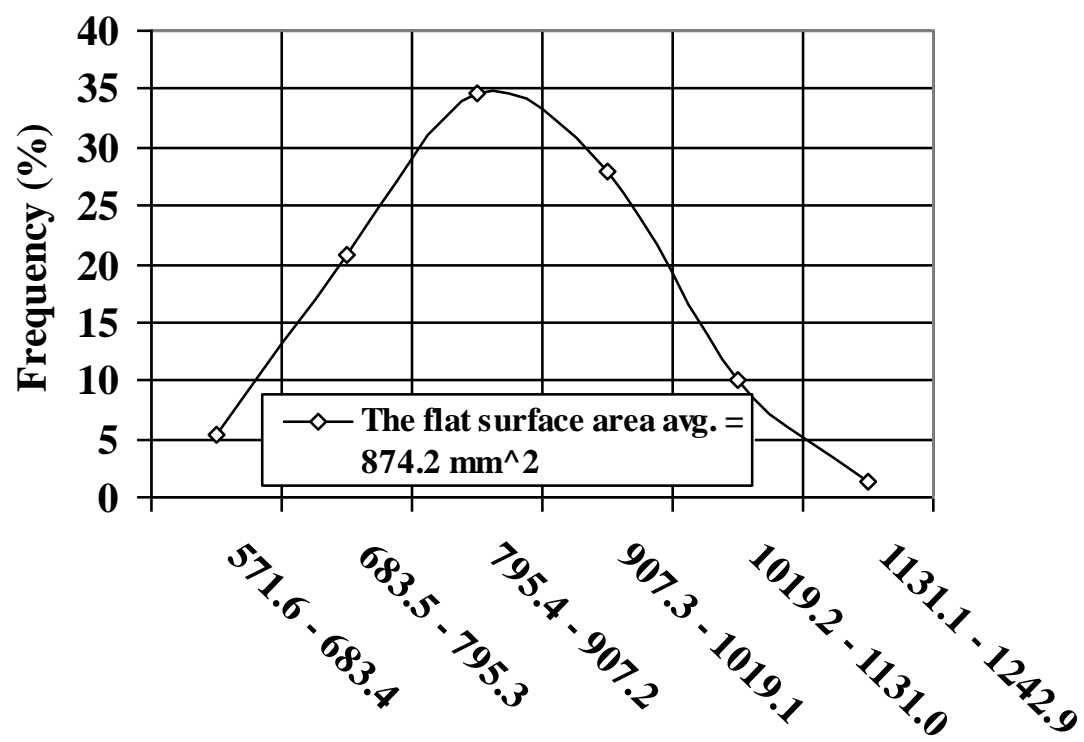

The flat surface area categories $\left(\mathrm{mm}^{\wedge} 2\right)$

Fig. ( 5 ):The flat surface area $\left(\mathrm{mm}^{\wedge} 2\right)$ of individual date fruit.

Mass of 200 date fruits, real density, bulk density, void ratio and moisture content:

Measurements of mass of two hundred date fruits under study, real and bulk density; also, void ratio and moisture content were conducted in three replicates. 
Table (3) shows the other physical characteristics for the mass, real density, bulk density, void ratio and moisture content. It shows that the fruits gave values of $3680.2(\mathrm{~g}), 0.95\left(\mathrm{~g} / \mathrm{cm}^{3}\right), 0.36\left(\mathrm{~g} / \mathrm{cm}^{3}\right), 62.00 \%$ and $67.20 \%$ w.b \& $206.00 \%$ d.b for the previous characteristics respectively. Mass of two hundred date fruits is major considerations in designing containers. Bulk and real density are major considerations in designing the converting, drying, aeration and storage systems, bulk density is also considered for determination of paging capacity, designing, cleaning and grading equipment.

Table (3): The mass of two hundred date fruits, real density, bulk density, void ratio and moisture content.

\begin{tabular}{|c|c|c|c|c|c|c|}
\hline \multirow{2}{*}{$\begin{array}{l}\text { Date } \\
\text { fruits }\end{array}$} & $\begin{array}{l}\text { Mass } \\
(\mathrm{g})\end{array}$ & $\begin{array}{c}\text { Real density } \\
\left(\mathrm{g} / \mathrm{cm}^{3}\right)\end{array}$ & $\begin{array}{c}\text { Bulk } \\
\text { density } \\
\left(\mathrm{g} / \mathrm{cm}^{3}\right)\end{array}$ & $\begin{array}{c}\text { Void ratio } \\
(\%)\end{array}$ & \multicolumn{2}{|c|}{$\begin{array}{l}\text { Moisture } \\
\text { content } \\
(\%)\end{array}$} \\
\hline & 3680.2 & 0.95 & 0.36 & 62.00 & $\begin{array}{c}67.20 \\
\text { w.b }\end{array}$ & $\begin{array}{c}206.00 \\
\text { d.b }\end{array}$ \\
\hline
\end{tabular}

\section{Angle of repose and static friction coefficient:}

The angle of repose for date fruits of the investigated variety was $16.4^{\circ}$, $21.6^{\circ}$ and $26.1^{\circ}$ for glass, plywood and galvanized sheet respectively. The previous data can be utilized to storage containers to allow an easily sliding. Coefficient of friction is the tangent of dynamic angle of repose. The repose angle for date fruits of the investigated variety on the selected material surfaces including galvanized sheet, plywood and glass are shown in Fig (6).

The lowest values of static coefficient of friction for the date fruits were on plywood followed by glass, and the highest galvanized sheet, $(0.12$, 0.14 and 0.17 ) for the date fruits variety respectively.

It is recommended to use this material in the structure of storage containers. The static coefficient of friction for date fruits of the investigated variety on the selected material surfaces including galvanized sheet, glass and plywood are shown in Fig (7).

\section{Rigidity force:}

The rigidity force of each date fruit in two surface positions (vertical and horizontal) was $15.99 \mathrm{~N}$ and $7.69 \mathrm{~N}$ respectively. 


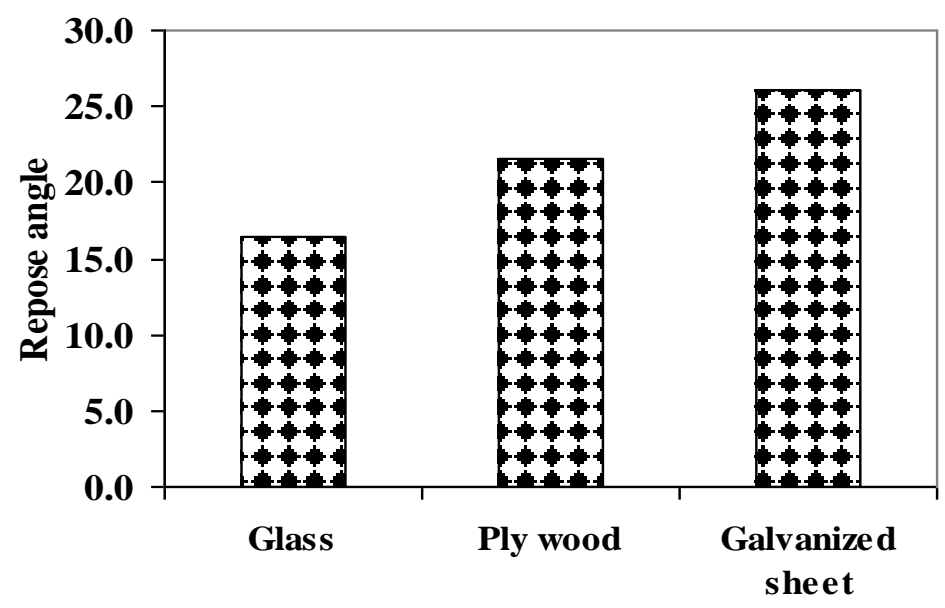

Type of surface

Fig.(6): Angle of repose for date fruits on different material surface.

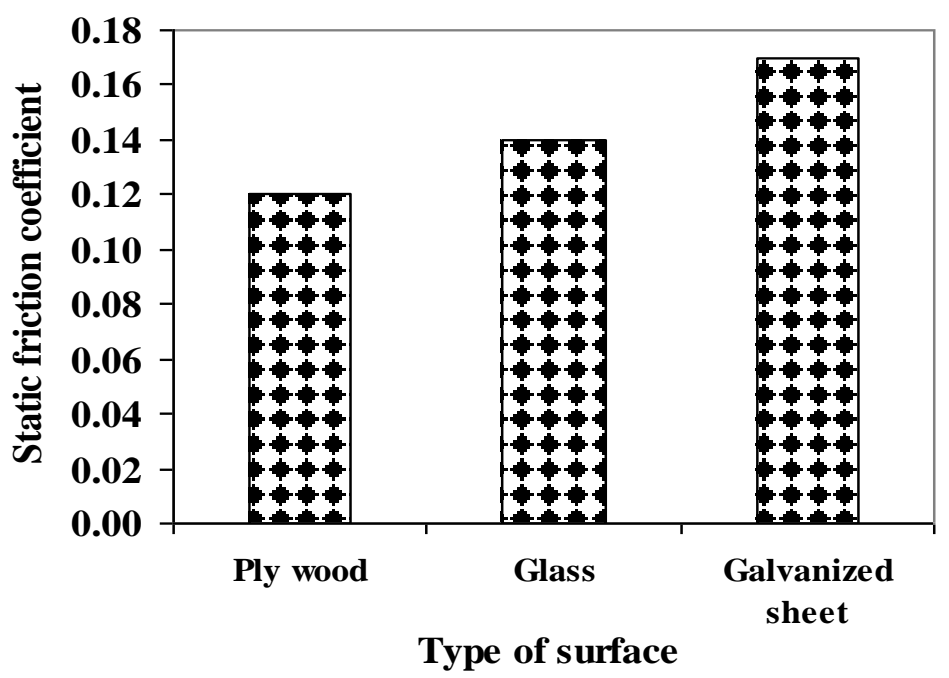

Fig. ( 7 ):Static friction coefficient for date fruits on different material surface.

\section{CONCLUSION}

The obtained results can be summarized as follows:

1- The highest values of the two- major dimensions were $42.9 \mathrm{~mm}$ for the diameter while the lowest value was $25.9 \mathrm{~mm}$ for the length.

2- The date fruits gave the highest of flat surface area of $1239.9 \mathrm{~mm}^{2}$, while the lowest value of $571.6 \mathrm{~mm}^{2}$. 
3- The values of $3680.2 \mathrm{~g}, 0.95 \mathrm{~g} / \mathrm{cm}^{3}, 0.36 \mathrm{~g} / \mathrm{cm}^{3}$ and $62.00 \%$ were for mass of two hundred date fruits, real density, bulk density and void ratio respectively.

4- The moisture content of $67.20 \%$ w.b and $206.00 \%$ d.b.

5- The highest value in repose angle of $26.10^{\circ}$ for galvanized sheet while the lowest value was $16.40^{\circ}$ for glass surface.

6- The lowest value of static coefficient of friction was 0.12 with glass surface while the highest value was 0.17 with galvanized sheet.

7- The rigidity force of $15.99 \mathrm{~N}$ and $7.69 \mathrm{~N}$ in two surface positions (vertical and horizontal) respectively.

\section{REFERENCES}

Abou-Elmagd, A.E., Hamam, A. S., EL-Saadany, M. A. and ElKawaga, S. A., 2002, Design of a cone-end detacher for orange picking, Misr. J. Ag. Eng. 19(2): 491-507.

Akubuo, C. O. and Odigboh, E. U., 1999, Egusi fruit coring machine. J. Agric. Eng. Res. 74: 121-126.

Al-Shahib, W., and Marshall, R.J., 2003, The fruit of the date palm: its possible use as the best food for the future?". International Journal of Food Sciences and Nutrition 54 (4): 247-259.

AOAC., 1995, Official methods of analysis ( $16^{\text {th }}$ ed.). Association of Official Analytical Chemists. Wash., DC.

Awady, M. N., Yehia, I. Hassan, M. A. and El Lithy, A. M., 2004, Some physical and mechanical properties of Minneola fruits, Misr J. Ag. Eng., 21(2): 669-684.

Boumans G., 1985, Grain handling and storage. Elsevier Sc. Pub. B. V. Amsterdam, Belgium.

El Sayed, G. H., Harb, S., Yehia, I., and Arif, E. M., 2009, Development of an automatic juicer for minneola fruits, Misr J. Ag. Eng., 34(4): 4155-4167

FAO 2012, Food and Agricultural Organization of the United Nations. Statistical Database- Agriculture. Accessed July 2012. http://faostat.fao.org/site/339/default.aspx 
Ismail, B., Haffar, I., Baalbaki, R., and Henry. J., 2001, Development of a total quality scoring system based on consumer preference weightings and sensory profiles: application to fruit dates (Tamr). Food Quality Preference, 12: 499-506.

Kaleemullah, S.,1992, The effect on moisture content on the physical properties of groundnut kernels. Tropical Sc., 32, 129-136.

Matthews, J., 1991, Progress in Agricultural physics and Engineering. (Hand Book). Chapter (8): 203-227.

Mohsenin, N. N., 1986, Physical properties of plant and animal materials, Gordon and Breach Sc. Pub., N. Y.

Myhara, R. M., Karkalas, J., and Taylor M. S., 1999, The composition of maturing Omani dates. Journal of the Science and Food Agriculture, 79, 1-6.

Nesvadba P., M. Houska, W. Wolf, V. Gekas, D. Jarvis, P.A. Saaad and Johns A. I, 2004, Database of physical properties of agroFood materials, J. of Food Eng.61:497-503.

Sawaya, W. N., Khalil, J. K., Safi, W. N., and Al-Shalhat A., 1983, Physical and chemical characterization of three Saudi date cultivars at various stages of development. Canadian Inst. Food Sc. and Tec., $16,87-91$.

Sawaya, W. N., Khatchadourian, H. A., Khalil, J. K., Safi, W. M., and Al-Shalhat A., 1982, Growth and compositional changes during various developmental stages of some Saudi Arabian date cultivars. J. Food Sc., 47: 489-492.

Soliman N.S., 1994, Effect of moisture content on angle of repose of paddy rice and its products. Misr, J. Ag. Eng. 11(1):163-173.

Waziri, A. and Mittal J. P. 1993, Design related physical properties of selected agricultural products. Agricultural mechanization in ASIA, Africa and Latin America. 14 (1): 20-23.

Yehia, I., Kabeel, M. H., and Abdel Galeel, M. M., 2009, Physical and mechanical properties of Ponkan mandarin applied to grading machine, Misr J. Ag. Eng. 26(2): 1036-1053. 


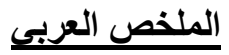

\section{بعض الخصائص الطبيعيه والميكانيكيه لثمار البلح * رزق ربيع كامل البسومي}

تهدف هذه الدراسة إلى توفير قاعدة معلومات للخصائص الطبيعية لثمار البلح "نوع جوزى" فى في الخى مرحلة قبل الرطب لما تمثله هذه الخو اص من أهمية فى عمليات حصـاد و تداول وتنظيف ثمـار

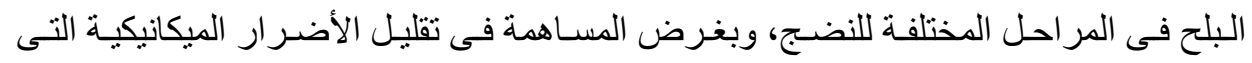

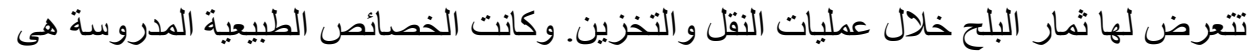

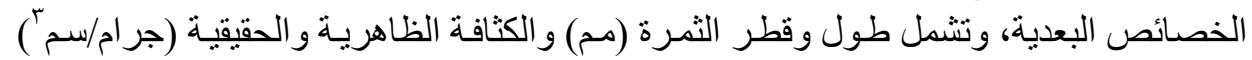

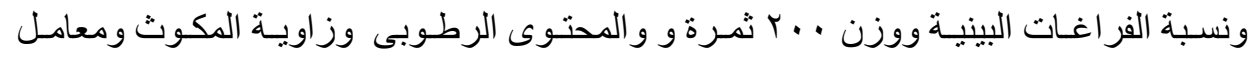

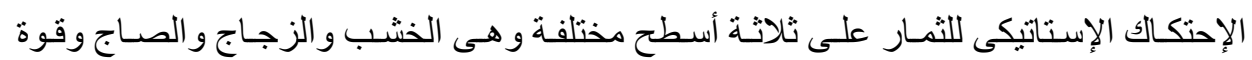
الإختر اق السطحية للثمار. ويمكن تلخيص النتائج التي توصل إليها البحث فيما ليلي:

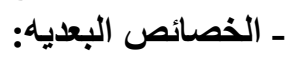

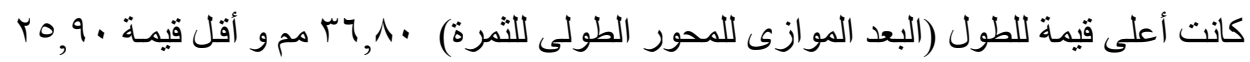

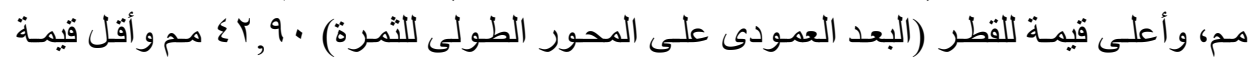

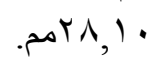

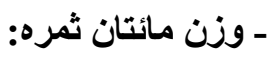

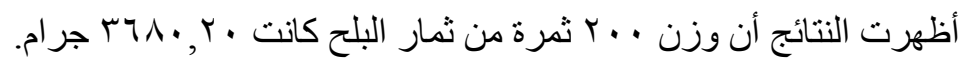

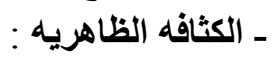

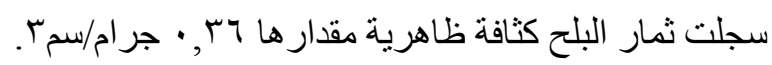

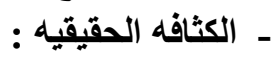

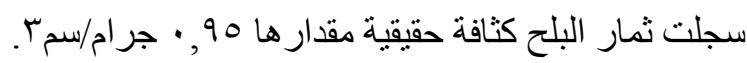

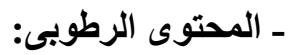

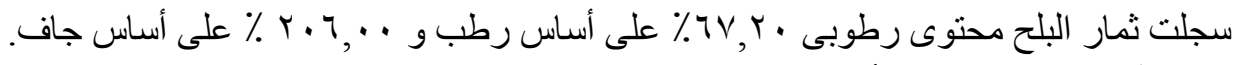

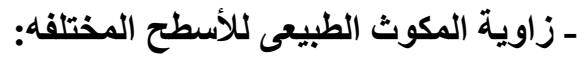

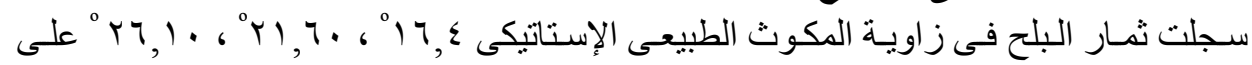

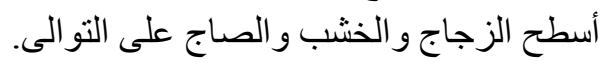

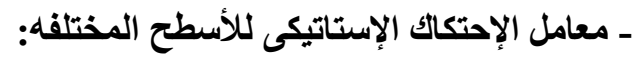

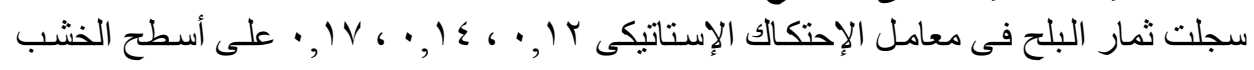
و الزجاج و الصاج على التو الى. فئ. ـ قوة الصلابة السطحيه:

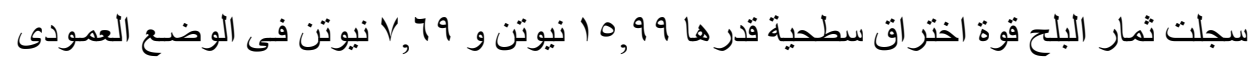
الأفقى على الترتيب.

*مدرس بقسم هندسة المنثآت الزراعية والتحم البيئى ـ كلية الهندسة الزراعية- جامعة الأزهر- القاهرة ـ مصر. 